\title{
11 \\ Challenges for Australian higher education in the Asian Century
}

Simon Marginson

\section{Introduction}

Australia is an odd construction: a nation with British/European heritage on the southeastern edge of Asia positioned between its history and its geography. While its demography is becoming more Asian, its flag still carries the imperial ensign. It needs to embrace both, but British antecedents have left it linguistically and culturally singular and it has yet to develop the cultural, political and intellectual resources to manage multiple identities. Thick multisectoral engagement will stimulate the formation of those resources. The former Gillard government's White Paper Australia in the Asian Century (the 'Henry Report') names higher education as one of the principal sectors through which Australia's regional engagement will develop. The White Paper states:

A growing proportion of global scientific research is taking place in Asia. Partnerships with research and technology communities are crucial to supporting Australia's ability to access new ideas and to build our future competitiveness (Commonwealth of Australia 2012: 266). 
As noted in the introduction to this book, the Abbott Liberal government has also encouraged engagement with Asian universities. This has a collaborative aspect and, for some, a competitive aspect. In 2014, Commonwealth Education Minister Christopher Pyne mentioned the need for Australian universities to be better resourced so as to compete with universities from China-as one justification for his proposal to introduce deregulated tuition fees (Pyne 2014). This chapter examines the challenges Australian universities face in engaging with universities in the Asian region.

There is some basis for optimism about higher education. After two decades of education exports, ties with the region have thickened and the gathering weight of universities in China and elsewhere enhances the pull factor. Australian universities still, however, connect better with North America, the United Kingdom and Western Europe than with Asia; and, apart from The Australian National University, they are building regional activity off a low base. While they are becoming more regionally involved, they are not yet regionally identified. The great transformation has yet to occur. Some in Australian universities, as in business and government, still see themselves operating as the British in Asia. That stance has no legs at all in the region. Australian universities can be part of the problem. All the same, the Henry Report is right: they are also part of the solution. Australian universities are enterprising institutions, the legacy of the Dawkins reforms of 1987-90 (Croucher et al. 2013); and many university leaders are alive to the modernisation dynamics in East Asia and parts of Southeast Asia, the emerging Asian universities and the potential thus created. Of course, Australian universities will need to move. Higher education and research science are highly globalised, and if the universities do not go with East Asia they will become undermined and marginalised even at home.

In this chapter, I analyse the changing geopolitics of knowledge, the rise of regional universities and the strategic implications for Australian higher education institutions.

\section{Global and regional patterns}

Though Australian universities and science are the products of post-1945 nationbuilding programs, it is impossible to fully understand them through the lens of 'methodological nationalism' - the idea that the nation-state is 'the natural and necessary form of society in modernity' (Cherlino 2007: 9-10). Increasingly, nations and institutions are conditioned by global and regional flows and patterns. At the same time, these flows and patterns are filtered through national and local systems, institutions and behaviours. Universities are all globalised, state-regulated and partly state-dependent. The past 25 years have seen a great worldwide expansion in the social and economic reach of higher education and 
research science, moving beyond the advanced industrial economies to include middle-income and developing nations. The spread of the research university is associated with communicative globalisation and networking (Marginson 201 lb), the growing economic role of knowledge-intensive work and technological innovations, urbanisation and the expansion of the middle class. The capitalist economy is absorbing pre-capitalist rural sectors in Asia, Africa and Latin America. Cities now house more than 50 per cent of the world's population. The European Union Institute for Strategic Economic Studies estimates the global middle class - people earning US\$10-100 a day - will increase from 1.8 billion in 2009 to 4.9 billion in 2030, including three billion in Asia (de Vasconcelos 2012: 28-30). Middle-class families want higher education.

From 2000 to 2010, the gross tertiary enrolment ratio (GTER) in East Asia and the Pacific rose from 16 to 29 per cent (UNESCO 2013). Research science has grown likewise. All nations now need capability in education, science and technology - though not all can pay for it - just as they need clean water, stable governance and globally viable finance.

Nations need universities that participate in the global knowledge network on an equal basis. Nations and cities without the capacity to interpret and understand research - a capacity that must rest on trained personnel capable of creating research - are locked into continued dependence. The growth of research is sustained by collaborations and the globalisation of knowledge within oneworld English-language science. It also takes the competitive form of an economic arms race in research and development $(\mathrm{R} \& \mathrm{D})$ and innovation in which global research rankings signify the competitive position. Between 1995 and 2009, Asian output of journal papers in science grew from 77,000 to almost 190,000 (NSF 2013). Capacity in higher education and science has been pluralised. In 2009, 48 countries published more than 1,000 science papers (Table 11.1) - a proxy for a science system that partly reproduces itself-compared with 38 in 1995 (NSF 2013). China, Hong Kong Special Administrative Region (SAR), Taiwan, South Korea in East Asia and Singapore in Southeast Asia have joined Japan as high-participation, high-science education and research systems. These 'postConfucian' systems (Marginson 2011a) ${ }^{1}$ share a dynamic growth trajectory.

\footnotetext{
1 In an earlier essay on East Asian higher education, I used the term 'Confucian model' (Marginson 2011 a). Respondents, especially those from East Asia, endorsed the description of East Asian-specific cultural elements but it was apparent that the term 'Confucian' carried unintended meanings reflecting prior usage in historical-cultural analysis and business studies as a form of cultural essentialism. It was never the intention to define all East Asian or educational phenomena as 'Confucian'. Cultural practices are not singular or fixed. Higher education and research in East Asia and Singapore are a complex, open and moving hybrid, shaped by indigenous elements, Western imperial intervention and the contemporary American research university. The term Confucian was not intended as a universal explanation but to emphasise two distinctive features of all higher education in the region: Confucian family practices of education as self-cultivation and social advancement, and the Sinic state. 'Post-Confucian' carries less unwanted baggage than 'Confucian'. It creates more space for hybridity with Western universities and global science. It should also be noted, however, that these post-Confucian states include liberal-capitalist democracies, socialist states and the Special Administrative Regions of Hong Kong and Macau.
} 
THE SOCIAL SCIENCES IN THE ASIAN CENTURY

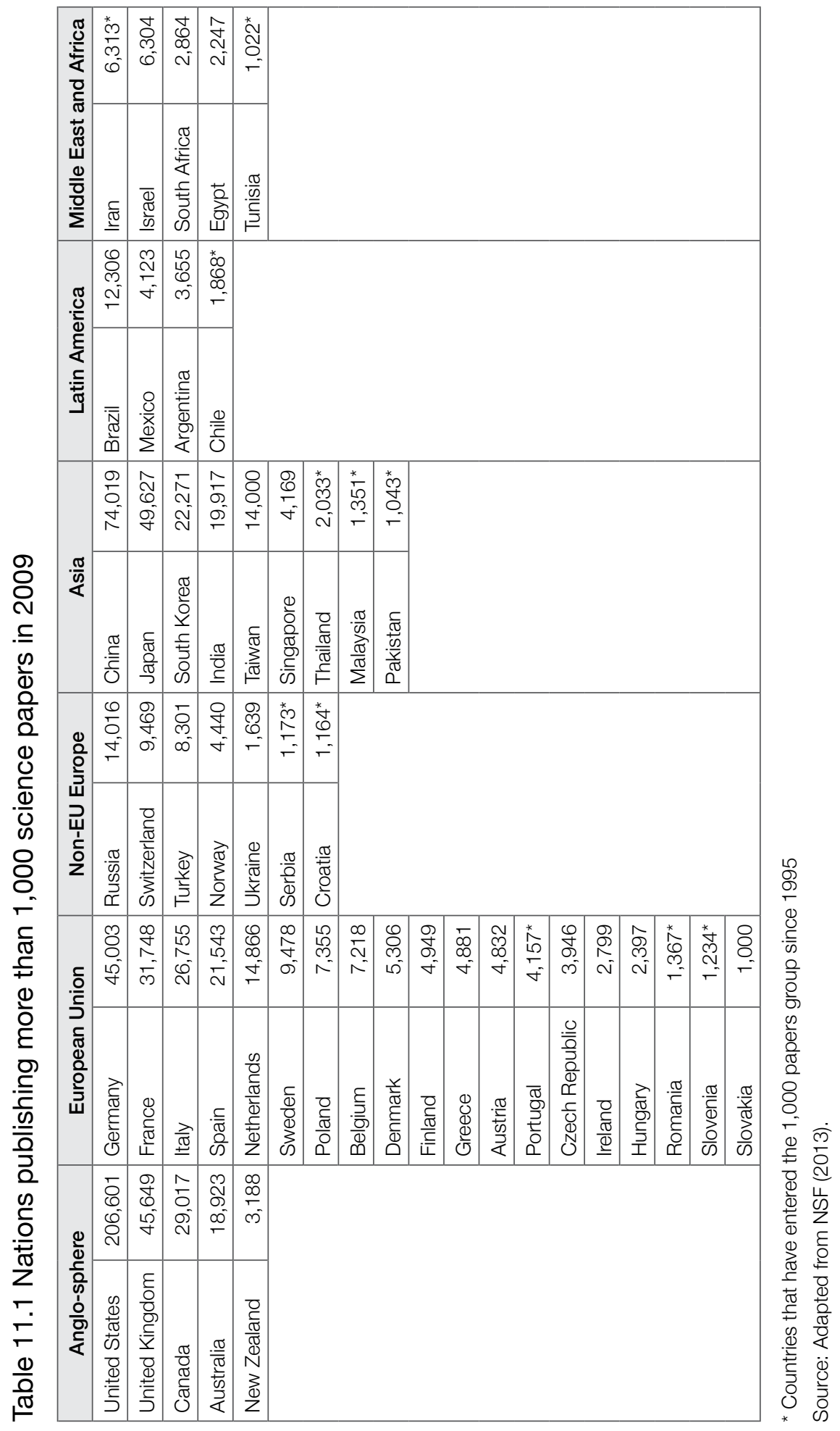


Table 11.2 Top-10 school systems in learning achievement of 15-yearolds in the three Program of International Student Assessment (PISA) disciplines, mean student scores, 2009

\begin{tabular}{|l|l|l|l|l|l|l|}
\hline \multicolumn{3}{|c|}{ Reading } & \multicolumn{2}{c|}{ Mathematics } & \multicolumn{2}{c|}{ Science } \\
\hline 1 & Shanghai China & 570 & Shanghai China & 613 & Shanghai China & 580 \\
\hline 2 & Hong Kong SAR & 545 & Singapore & 573 & Hong Kong SAR & 555 \\
\hline 3 & Singapore & 542 & Hong Kong SAR & 561 & Singapore & 531 \\
\hline 4 & Japan & 538 & Taiwan & 560 & Japan & 547 \\
\hline 5 & South Korea & 536 & South Korea & 554 & Finland & 545 \\
\hline 6 & Finland & 524 & Macau SAR & 538 & Estonia & 541 \\
\hline 7 & Taiwan & 523 & Japan & 536 & South Korea & 538 \\
\hline 8 & Canada & 523 & Liechtenstein & 535 & Vietnam & 528 \\
\hline 9 & Ireland & 523 & Switzerland & 531 & Poland & 526 \\
\hline 10 & Poland & 518 & Netherlands & 523 & Liechtenstein/Canada & 525 \\
\hline \multirow{4}{*}{} & Australia (19 ${ }^{\text {th }}$ ) & 504 & Australia (eq. $13^{\text {th }}$ ) & 512 & Australia (eq. $19^{\text {th }}$ ) & 521 \\
\cline { 2 - 6 } & United Kingdom & 499 & United Kingdom & 494 & United Kingdom & 514 \\
\cline { 2 - 6 } & United States & 498 & United States & 481 & United States & 497 \\
\hline
\end{tabular}

Source: Adapted from OECD (2013b).

Unlike Europe, in East Asia higher education is not moving on the basis of regulated regional cooperation, but it is moving in parallel. The post-Confucian countries differ from each other in many ways including language and political systems. There are tensions. Nevertheless, they have four common features that have facilitated their take-off: the comprehensive and active Sinic state, Confucian educational practices at home, internationalisation strategies that enable them to rapidly absorb Western modernisation in higher education and science, and economic growth sufficient to pay for educational infrastructure and research.

\section{Higher education and research in East Asia and Singapore}

\section{Participation in tertiary education}

Despite diversity in political and economic systems, the countries I have characterised as the post-Confucian systems are moving towards universal participation. The GTER exceeds 85 per cent in South Korea and Taiwan; Macau SAR is at 65 per cent and Japan and Hong Kong SAR at 60 per cent. Hong Kong and Singapore are moving away from the non-universal systems inherited 
from Britain by building subdegree numbers. In China the GTER moved from 5 per cent to 26 per cent between 1990 and 2010 (UNESCO 2013). The 2020 target is 40 per cent, which is near the present Organisation for Economic Cooperation and Development (OECD) average. Institutional quality varies. The top-200 universities have been lifted. The challenge is to improve other institutions and lift participation in the poorer provinces. Nevertheless, the post-Confucian systems largely avoid the Anglo-American trade-off between advances in quality and in quantity.

Government and households share the cost of participation, enabling the state to focus part of its funding on elite national research universities, their students and (in some systems) social equity. A feature of post-Confucian systems -in marked contrast with Europe - is that poor families often invest heavily in schooling, extra tutoring and classes. Post-Confucian families can spend as much on education as Australians spend on housing. In Korea in 2010, 72.7 per cent of the cost of tertiary institutions was paid privately, including 47.1 per cent by households, with 27.3 per cent financed by government. In Japan, the private sector share was 65.6 per cent (OECD 2013a: 207); in China about 40 per cent. Levin (2011) finds Koreans spend 3 per cent of gross domestic product (GDP) on non-formal schooling.

Public and private investment in schooling, combined with parental focus on student achievement, state reform programs and the pressure of examinations, prepare post-Confucian students for tertiary education at an advanced level (Table 11.2). The 2012 OECD Program of International Student Assessment (PISA) found that in mean student scores in mathematics, the top-seven systems in the world were Shanghai (613), Singapore (573), Hong Kong SAR (561), Taiwan (560), South Korea (554), Macau SAR (538) and Japan (536). Post-Confucian systems performed almost as well in PISA science, with the top-four systems, and in PISA reading, with the top-five systems (OECD 2013b).

\section{Research science}

Except in China, post-Confucian investment in R\&D as a proportion of GDP is on par with Western Europe. South Korea invested 3.74 per cent of GDP in 2010, and Taiwan 2.9 per cent, compared with 3.96 per cent in Finland, 2.88 per cent in the United States and 2.21 per cent in Australia (NSF 2013). China's investment was 1.7 per cent of GDP. It is increasing investment by 0.1 per cent a year. The national target is 2.5 per cent by 2020 . 
Figure 11.1 Total spending on R\&D, top 11 countries, 2000 and 2010, US\$ billion

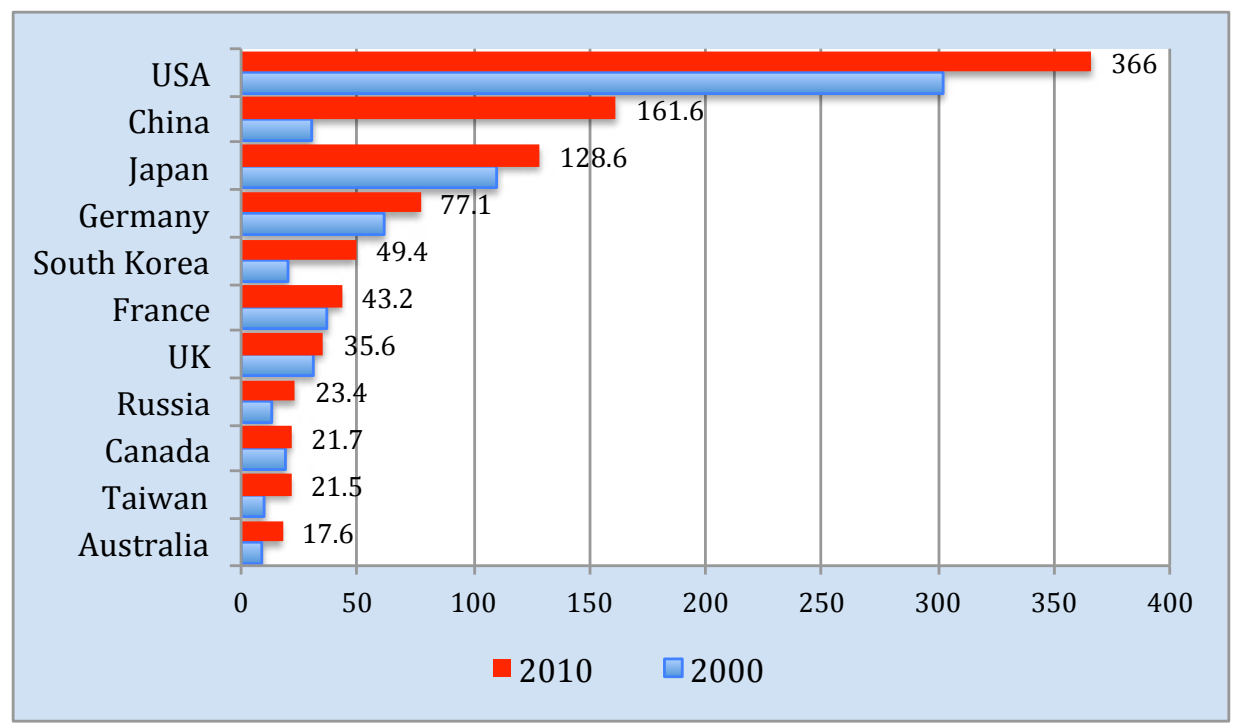

Data for 2010 or nearest year, expressed in constant 2005 USD

Source: Adapted from OECD (2013c).

If spending continues to grow at this rate, China's R\&D will pass that of the United States in the next five years. As in South Korea, in China, a relatively low proportion of spending goes to universities - one yuan in 10-but the universities access other government monies by partnering with the state enterprises that conduct most R\&D in China. East Asia now invests more than Europe and the United Kingdom combined. In 2009 North America invested $\$ 433$ billion in R\&D, Europe \$319 billion and East, Southeast and South Asia $\$ 402$ billion - 31.5 per cent of the global total (NSF 2013).

Figure 11.1 shows that three of the world's five largest R\&D investor nations are post-Confucian - China, Japan and South Korea-while Taiwan is in the top 10 (OECD 2013c). In constant 2005 prices, China's R\&D rose from $\$ 30.4$ billion in 2000 to $\$ 161.6$ billion in 2010 - multiplying by five times in a decade. Post-Confucian research systems are strongly biased towards applied research and commercialisation. Basic university research is less well supported proportionately than in the United States or Western Europe. Nevertheless, with all research budgets rising, except in Japan, both university research funding and scholarly papers are growing vigorously (again, except in Japan). 
Figure 11.2 Number of journal papers produced in 2009, 14 leading countries

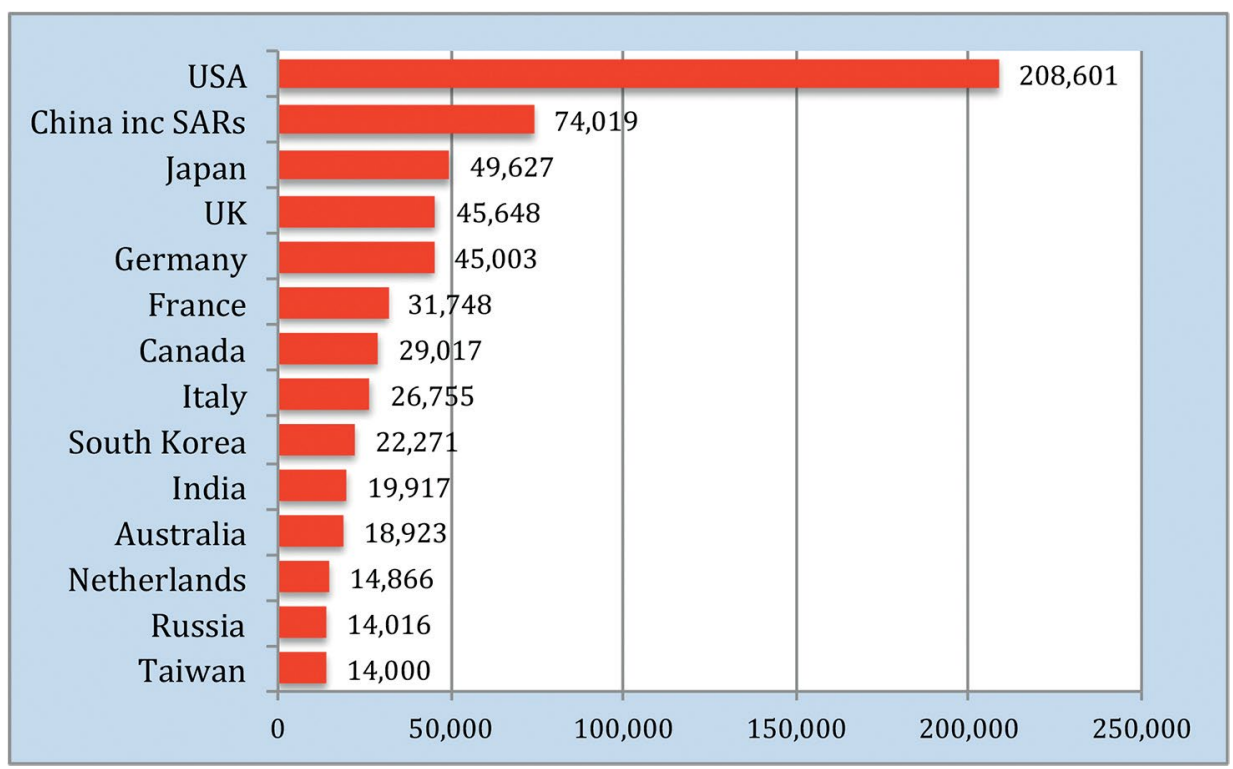

Source: Adapted from NSF (2013).

Figure 11.2 is based on ISI/Thomson Web of Knowledge data, which include economics, demography, psychology, sociology and some education as well as physical and life sciences and applied sciences. Legitimate questions have been raised about how effective ISI/Thomson's global reach really is (Connell in this volume; Cruz 2008). Nonetheless, it serves as one indicator of the forward march of the post-Confucian science systems: the coverage of English-language publishing in the orthodox sciences, at least, is comprehensive. In 2009 two of the three largest science producers were post-Confucian and South Korea was in ninth place, ahead of Australia, while Taiwan was in fourteenth place (NSF 2013).

Of the non-post-Confucian systems in Asia, Singapore produced 4,187 papers in 2009, Thailand 2,033, Malaysia 1,351 and Pakistan 1,043. The world's fourth most populous nation, Indonesia, had 262 papers. There were 260 in Bangladesh, 223 in the Philippines and 326 in post-Confucian Vietnam (where the nation is too poor for the take-off) - all with large populations but lacking indigenous science systems. Journal papers are largely the work of doctoral students abroad. On graduation, such students typically either migrate to the nation of education or return home to career positions but leave the field of research. 
Figure 11.3 Output of journal papers in science, 1995 to 2009, seven countries

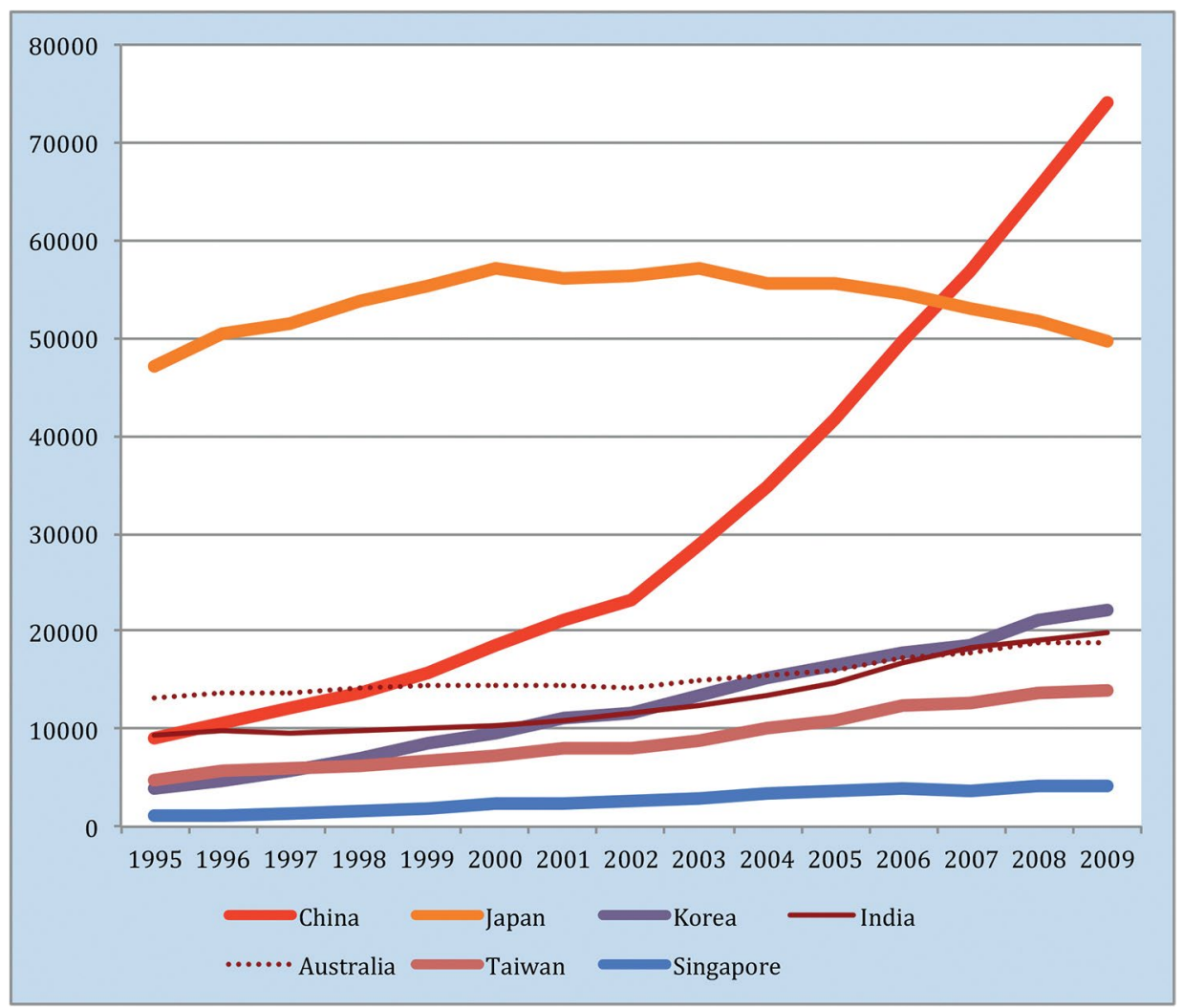

Source: Adapted from NSF (2013).

The advance of Chinese science is extraordinary (Figure 11.3). China was the world's twelfth-largest producer in 1995; it was second in 2009. Since 2000, annual output has grown by 17 per cent per year. When the world's largest nation expands research at unprecedented rates over a prolonged period, global knowledge flows are decisively changed. In future, much of human knowledge will come from China. The growth of science has been almost as rapid in South Korea, where annual output has now passed that of India, even though India has 30 times the population of South Korea. Journal paper output has also ballooned in Singapore and Taiwan. In 1995 India produced more research papers than China but growth has begun to quicken only in the past half-decade, stimulated by central government funding of R\&D. Japan's science system matured in the 1970s and 1980s and the annual number of papers is now falling (NSF 2013).

Research quantity has moved ahead of research quality. In 2010 China, Japan, Korea, Taiwan, Singapore, India, Thailand, Malaysia, Indonesia and the Philippines produced 21.9 per cent of all science papers, but only 10.6 per cent 
of papers in the top 1 per cent by citation rate. The United States produced 27.8 per cent of papers and 48.9 per cent of the top 1 per cent of papers. China published 7.5 per cent of papers and 3.6 per cent of the top papers. The patterns are uneven by discipline. The strengths of post-Confucian research systems are in the physical science-based disciplines, which underpin transport, communications, energy, urban construction and infrastructure. In engineering, chemistry, computer science, physics and mathematics, China's share of published research is relatively high - in engineering, China had 12.5 per cent of all papers and 12.3 per cent of the top 1 per cent - and quality is improving rapidly. In 2000 China had 0.6 per cent of the top 1 per cent most cited chemistry papers; in 2010 it had 10.6 per cent. In medicine and biological sciences, however, China generated less than 1 per cent of the top papers in 2010 (NSF 2013).

Note that in Figure 11.3 Australia began in 1995 as the largest research producer after Japan. In 2009 it was fifth, behind China, Japan, South Korea and India.

\section{World-class universities}

Governments in East Asia and Singapore place a high priority on developing 'world-class universities' (WCUs), concentrations of status and research comparable with North America and the United Kingdom/Western Europe. WCU policy builds on pre-given national hierarchies, like the pre-World War II imperial universities in Japan, Peking University (1898) in China and Seoul National University (1946) in Korea. There are also successful more recent foundations, such as the Hong Kong University of Science and Technology, which opened in 1991 (Postiglione 2011). WCUs are supported by special investment funding such as the 211 and 985 programs in China and Brain 21 in Korea (Shin 2009).

It takes time for WCU investment to show in global rankings. There are lags between investment and published science, between publication and citation, and between citation and change in the rankings. China's investment is now beginning to secure results. In the Shanghai Academic Ranking of World Universities (ARWU 2013), the number of top-500 universities in mainland China increased from 8 to 28 between 2005 and 2013. There were five more in Hong Kong SAR. In 2011 Tsinghua was the only top-200 university; in 2013 there were five: Tsinghua, Peking, Zhejiang, Fudan and Shanghai Jiao Tong. Investments in $\mathrm{R} \& \mathrm{D}$ now taking place will show in the rankings in 10 to 15 years, though the full effects will take a generation or more. By 2025-30, leading universities in China, South Korea, Taiwan and Singapore will be highly placed and there will be many more in the top 200. 
The Shanghai ranking also lists the top-100 institutions in five broad research fields. There are 24 post-Confucian universities in the world top 100 in engineering; China and Taiwan between them have 16. The City University of Hong Kong is twenty-fifth in the world, Hong Kong University of Science and Technology thirty-fourth, alongside Tsinghua. National Taiwan University, a major player in computing research, is twenty-sixth. Australia has five engineering schools in the world top 100 but none in the top 50 (ARWU 2013).

A more precise picture is provided by the Leiden University Centre for Science and Technology Studies (Leiden 2013). It ranks universities using separated single indicators, including volume of science papers, citations, cites per paper and papers in the top 10 per cent of their field by citation rate. ${ }^{2}$ Table 11.3 lists the 30 leading Asia-Pacific universities, including Australian universities, by their number of top 10 per cent papers (second-last column). The table also includes total papers and proportion of papers in the top 10 per cent. Despite the limits of citation counts as a measure of quality, including the omission of much of social science and all humanities, the second-last column in Table 11.3 is a useful summary of the scientific firepower of a university-its 'quantity of quality' in research.

Eight regional universities produce more than the University of Sydney. The two Singapore institutions are large research producers with a high percentage of top 10 per cent papers. In terms of total output and highly cited papers, the National University of Singapore is as strong as European universities other than Oxford and Cambridge. There are 12 mainland Chinese universities in the top 30, plus three from Hong Kong. Tsinghua and Peking universities have citation rates comparable with leading Australian universities of equivalent size. There is an interesting group of small to medium-sized science and technology specialists. Nankai and the University of Science and Technology in China have excellent citation rates, as do the three Hong Kong universities and Hong Kong University of Science and Technology and Postech in Korea, which are both too small to figure in the table (Leiden 2013).

Of the world's top-100 universities by proportion of papers in the top 10 per cent of their field, 17 are in the Asia-Pacific region, including five in Australia. One regional university is in the world top 30: the National University of Singapore (twenty-ninth). On this measure, Australia's strongest university is Melbourne, at forty-first in the world and third in the region. Melbourne has moved ahead of The Australian National University in all the citation quality indicators in the Leiden ranking.

2 The citation data are provided in both raw form and on a field-normalised basis, whereby the Leiden group adjusts the raw data to account for different rates of publication and citation in research fields. 
THE SOCIAL SCIENCES IN THE ASIAN CENTURY

Table 11.3 Thirty leading research universities in the Asia-Pacific, on the basis of number of science papers in 2008-11 in the top 10 per cent of the research field on citation rate (per cent)

\begin{tabular}{|c|c|c|c|c|}
\hline University & $\begin{array}{c}\text { Total journal } \\
\text { papers } \\
2008-11\end{array}$ & $\begin{array}{l}\text { Proportion of } \\
\text { papers in } \\
\text { top } 10 \% \text { by } \\
\text { citation }\end{array}$ & $\begin{array}{l}\text { Number of } \\
\text { papers in } \\
\text { top } 10 \% \text { by } \\
\text { citation }\end{array}$ & $\begin{array}{l}\text { World rank } \\
\text { on number } \\
\text { of papers in } \\
\text { top } 10 \%\end{array}$ \\
\hline Harvard University (USA) & 29,812 & 21.8 & 6,492 & 1 \\
\hline University of Cambridge (UK) & 11,742 & 17.1 & 2,009 & 11 \\
\hline $\begin{array}{l}\text { National University of Singapore } \\
\text { (Singapore) }\end{array}$ & 9,890 & 13.7 & 1,353 & 29 \\
\hline University of Tokyo (Japan) & 14,175 & 9.0 & 1,274 & 31 \\
\hline University of Melbourne (Australia) & 8,516 & 13.0 & 1,111 & 41 \\
\hline Zhejiang University (China) & 11,427 & 9.2 & 1,054 & 45 \\
\hline Tsinghua University (China) & 8,891 & 11.7 & 1,037 & 47 \\
\hline Kyoto University (Japan) & 11,343 & 8.6 & 980 & 49 \\
\hline $\begin{array}{l}\text { University of Queensland } \\
\text { (Australia) }\end{array}$ & 7,858 & 12.3 & 970 & 51 \\
\hline $\begin{array}{l}\text { Nanyang University of Technology } \\
\text { (Singapore) }\end{array}$ & 6,673 & 13.7 & 912 & 59 \\
\hline Peking University (China) & 8,419 & 10.8 & 905 & 60 \\
\hline University of Sydney (Australia) & 8,655 & 10.3 & 894 & 61 \\
\hline $\begin{array}{l}\text { Seoul National University (South } \\
\text { Korea) }\end{array}$ & 10,799 & 8.1 & 871 & 64 \\
\hline $\begin{array}{l}\text { Shanghai Jiao Tong University } \\
\text { (China) }\end{array}$ & 9,899 & 7.8 & 770 & 81 \\
\hline Fudan University (China) & 7,076 & 10.7 & 756 & 83 \\
\hline Monash University (Australia) & 6,345 & 11.2 & 711 & 94 \\
\hline Osaka University (Japan) & 8,714 & 7.8 & 681 & 96 \\
\hline $\begin{array}{l}\text { University of New South Wales } \\
\text { (Australia) }\end{array}$ & 6,322 & 10.8 & 680 & 97 \\
\hline $\begin{array}{l}\text { University of Science and } \\
\text { Technology (China) }\end{array}$ & 4,914 & 13.3 & 653 & 100 \\
\hline $\begin{array}{l}\text { University of Hong Kong (Hong } \\
\text { Kong SAR) }\end{array}$ & 5,820 & 11.2 & 651 & 101 \\
\hline Tohoku University (Japan) & 8,654 & 6.7 & 579 & 117 \\
\hline Nanjing University (China) & 5,724 & 10.1 & 578 & 118 \\
\hline $\begin{array}{l}\text { Chinese University of Hong Kong } \\
\text { (Hong Kong SAR) }\end{array}$ & 4,998 & 10.7 & 533 & 133 \\
\hline Nankai University (China) & 3,673 & 14.4 & 531 & 136 \\
\hline Sun Yat-Sen University (China) & 5,624 & 9.4 & 527 & 139 \\
\hline $\begin{array}{l}\text { The Australian National University } \\
\text { (Australia) }\end{array}$ & 4,209 & 12.1 & 511 & 144 \\
\hline
\end{tabular}




\begin{tabular}{|l|r|r|r|r|}
\hline University & $\begin{array}{c}\text { Total journal } \\
\text { papers } \\
\mathbf{2 0 0 8 - 1 1}\end{array}$ & $\begin{array}{c}\text { Proportion of } \\
\text { papers in } \\
\text { top 10\% by } \\
\text { citation }\end{array}$ & $\begin{array}{c}\text { Number of } \\
\text { papers in } \\
\text { top 10\% by } \\
\text { citation }\end{array}$ & $\begin{array}{c}\text { World rank } \\
\text { on number } \\
\text { of papers in } \\
\text { top 10\% }\end{array}$ \\
\hline $\begin{array}{l}\text { Korea Advanced Institute of S\&T } \\
\text { (South Korea) }\end{array}$ & 4,483 & 11.2 & 500 & 149 \\
\hline Jilin University (China) & 4,986 & 9.8 & 490 & 152 \\
\hline $\begin{array}{l}\text { Harbin Institute of Technology } \\
\text { (China) }\end{array}$ & 5,202 & 9.3 & 486 & 155 \\
\hline Shandong University (China) & 5,592 & 8.4 & 468 & 169 \\
\hline Yonsei University (South Korea) & 6,592 & 7.1 & 466 & 170 \\
\hline $\begin{array}{l}\text { Hong Kong Polytechnic University } \\
\text { (Hong Kong SAR) }\end{array}$ & 4,054 & 10.9 & 440 & 183 \\
\hline
\end{tabular}

Source: Adapted from Leiden (2013).

\section{Dynamics of the post-Confucian model}

Beginning with Japan in the 1960s to 1980s, followed by Taiwan, Korea and Singapore in the 1990s, and China in the past decade, the post-Confucian systems have achieved three objectives simultaneously: the generalisation of participation, the rapid growth of research science, and world-class universities. No other system of higher education and university research has moved forward at this pace in all three areas - and the post-Confucian systems have done it within low-tax polities. In 2007, public spending as a share of GDP was less than 15 per cent in Hong Kong SAR, Japan and Taiwan, 19.3 per cent in China and 20.8 per cent in Korea (ADB 2010), compared with more than 50 per cent in parts of Europe.

How was it done? What are the conditions and drivers? As noted above, the key elements have been economic growth - all post-Confucian countries except China and Vietnam now enjoy per capita incomes at Western European levels the distinctive Sinic state, Confucian educational practices in the home, and state-driven internationalisation strategies.

The comprehensive and centralising Sinic state originated in China's Qin and Han dynasties in the third century BCE and has followed a different path to the limited liberal state of John Locke and Adam Smith. Perhaps it is better equipped than Western states for the accelerated upgrading of universities and R\&D. In the limited liberal state, the state's right to tax and intervene is habitually questioned, whereas East Asians mostly accept the state as supervisor of society and social conduct. Dissidents, as in Tiananmen Square in 1989, rarely rail against the legitimacy of state action as such. Rather they call on the state to discharge its responsibilities in a proper manner, to behave as a state should behave: 
In the East Asian cultural context, government leadership is deemed indispensable for a smooth functioning of the domestic market economy and vital for enhancing national comparative advantage in international competition. The central government is expected to have a holistic vision of the well-being of the nation and a long-term plan to help people maintain an adequate livelihood ... Strong government with moral authority, a sort of ritualized symbolic power fully accepted by the overwhelming majority, is acclaimed as a blessing. (Tu 1996: 7)

The post-Confucian states see higher education and research as essential to economic growth and global effectiveness. They take the long view of their role. Government as a vocation has higher standing than in English-speaking countries. Many of the best graduates from top universities head for state office, not the professions or business.

In the home, the Confucian commitment to self-cultivation via learning was first established on a mass basis in the Song Dynasty 1,000 years ago. Post-Confucian respect for education is more deeply rooted than in Europe and North America, where mass education dates from the nineteenth century. For example, prior to the mid-nineteenth-century Western intervention in Japan, school participation, especially among females, was equal to or greater than in Europe. The 11,000 village schools were a strong basis for Meiji modernisation (Henshall 2007: 43). Education is seen as part of the duty of child to parent and the duty of parent to child, the source of personal virtue, social standing and meritocratic advance. The family and individual schooling are joined to social ordering by the 'oneoff' examination systems that select students into the leading universities.

East Asian higher education is also shaped by norms and models from Europe and the American research university, entrenched through relentless internationalisation programs (Wang et al. 2011): sponsored mobility of students and scholars and measures to attract back the diaspora; recruitment of foreign scholar-researchers; English language learning, incentives for global publishing in English, and English medium graduate studies and international education; benchmarking of universities and disciplines against counterparts in North America and Europe, and rankings to drive WCU ambitions; and new public management reform of organisation. Since Meiji Japan, catch-up with the West has been the policy driver, though competition with other Asian nations is increasingly important. The post-Confucian systems of higher education and research are East-West hybrids. They are also something new: a distinctive post-Confucian form of modernisation. Western influence has not displaced educational or political tradition. The relation between tradition and modernity is one of exchange, not displacement. Much of the potency of the post-Confucian model of education derives from its indigenous elements: Confucian tradition at home and the constructive state policy. 


\section{Partnerships with rising Asia}

Australia has five universities in the ARWU top 100-the University of Melbourne, The Australian National University, the University of Queensland, the University of Western Australia and the University of Sydney - though none in the top 50. The Leiden data position the top Australian research universities as equivalent to the top regional universities rather than ahead of them, and behind Singapore and some science and technology universities in citation quality. Australia is above world average citation rates in 17 of 20 disciplines, but only five disciplines are above the European average: veterinary science, energy, engineering, earth and planetary science, and medicine. The United Kingdom is above the European average in all disciplines (Chubb 2013). While the leading Australian institutions perhaps have the firepower to partner in Asia, what do they bring to potential partnerships that is superior to the United Kingdom, the United States and Canada? Are they making use of their priceless geographical proximity to deepen the cultural interface?

This raises the question of regional identity, which is both geographical and cultural. In the global setting, regional formation in higher education (and other spheres) depends on four elements. First, systems must be sufficiently resourced to enable partnership and not dependency. Second, geographical proximity is important. Third, common cultural elements, as in Iberian Latin America, are significant. Fourth, political will is necessary. National education systems must want to regionalise, as with the Bologna Accord in Europe and the European Research Area. At this stage, the post-Confucian countries fulfil the first three conditions but the will is weak. The Association for Southeast Asian Nations (ASEAN) has the political will to develop regionally but, with the exception of Singapore, its higher education systems are underdeveloped, and there is less cultural commonality than in post-Confucian Asia or Western Europe. Both Northeast Asia and Southeast Asia have limited themselves to smallscale mobility schemes such as staff and student exchanges between leading universities.

Given that regional consciousness is embryonic, collective inclusion of Australian higher education in Asian higher education is not a prospect. Australia is on the geographical edge; there is no will to bring Australia in, and there is a cultural gulf between Australia and most regional systems with the partial exception of Hong Kong and Singapore. The only potential for Australian-Asian regional structures is in research (to be discussed below). Australian integration into Asian higher education is a matter for bilateral negotiations and one-toone dealings between institutions. Here, to work more effectively, Australian 
universities will need to deepen their cultural understanding of East Asia and its nations. Australia, with its relative strength in Asian studies and Asian languages, is well placed to do so.

\section{The cross-cultural dimension}

There is more than one kind of state and more than one kind of university. Political and educational cultures condition the potentials of government and where universities collaborate. Most systems are partly regional, reflecting historical overlaps and clustered cultures. Informal regional groupings include post-Confucian, Westminster and US systems, Nordic (Valimaa 2011), Germanic, Francophone, Russian (Smolentseva 2003), Latin American (Marginson 2012), South Asian, and Saudi Arabian and the Gulf states.

Table 11.4 compares post-Confucian, US and Westminster systems.

\section{Table 11.4 Comparison of post-Confucian and English-language country systems}

\begin{tabular}{|l|l|l|l|}
\hline & $\begin{array}{l}\text { Post-Confucian systems } \\
\text { (East Asia \& Singapore) }\end{array}$ & US system & $\begin{array}{l}\text { Westminster systems } \\
\text { (UK, Australia, New Zealand) }\end{array}$ \\
\hline $\begin{array}{l}\text { Character of } \\
\text { nation-state }\end{array}$ & $\begin{array}{l}\text { Comprehensive, central, } \\
\text { delegates to provinces. } \\
\text { Politics in command of } \\
\text { economy and civil society. } \\
\text { State draws best graduates }\end{array}$ & $\begin{array}{l}\text { Limited, division of } \\
\text { powers, separate } \\
\text { from civil society } \\
\text { and economy. Anti- } \\
\text { statism common. } \\
\text { Federal }\end{array}$ & $\begin{array}{l}\text { Limited, division of powers, } \\
\text { separate from civil society and } \\
\text { economy. Some anti-statism. } \\
\text { Unitary }\end{array}$ \\
\hline $\begin{array}{l}\text { Educational } \\
\text { culture }\end{array}$ & $\begin{array}{l}\text { Confucian commitment to } \\
\text { self-cultivation via learning. } \\
\text { Education as filial duty } \\
\text { and producer of status } \\
\text { via exam competition } \\
\text { (and producer of global } \\
\text { competitiveness) }\end{array}$ & $\begin{array}{l}\text { Twentieth-century } \\
\text { meritocratic and } \\
\text { competitive ideology. } \\
\text { Education common } \\
\text { road to wealth/ } \\
\text { status, within } \\
\text { advancing prosperity }\end{array}$ & $\begin{array}{l}\text { Post-1945 ideology of state- } \\
\text { guaranteed equal opportunity } \\
\text { wealth and status, open to all } \\
\text { in society }\end{array}$ \\
\hline $\begin{array}{l}\text { State role } \\
\text { in higher } \\
\text { education }\end{array}$ & $\begin{array}{l}\text { Big. State supervises, } \\
\text { shapes, drives and } \\
\text { selectively funds } \\
\text { institutions. Over time } \\
\text { increased delegation to } \\
\text { part-controlled presidents }\end{array}$ & $\begin{array}{l}\text { Smaller, from } \\
\text { distance. Fosters } \\
\text { market ranking via } \\
\text { research, student } \\
\text { loans. Then steps } \\
\text { back. Autonomous } \\
\text { presidents }\end{array}$ & $\begin{array}{l}\text { From distance. Policy, } \\
\text { regulation, funding supervise } \\
\text { market, shape activity. } \\
\text { Autonomous vice-chancellors }\end{array}$ \\
\hline $\begin{array}{l}\text { Financing } \\
\text { of higher } \\
\text { education }\end{array}$ & $\begin{array}{l}\text { State-financed } \\
\text { infrastructure, part of tuition } \\
\text { (especially early in model), } \\
\text { scholarships, merit aid. } \\
\text { Household funds much } \\
\text { tuition and private tutoring, } \\
\text { even in poor families }\end{array}$ & $\begin{array}{l}\text { State funds some } \\
\text { infrastructure, tuition } \\
\text { subsidies, student } \\
\text { loans. Households } \\
\text { vary from high tuition } \\
\text { to low, poor families } \\
\text { state dependent }\end{array}$ & $\begin{array}{l}\text { Less state-financed } \\
\text { infrastructure now. Tuition } \\
\text { loans, some aid. Growing } \\
\text { household investment but less } \\
\text { than East Asia. Austerity }\end{array}$ \\
\hline
\end{tabular}




\begin{tabular}{|l|l|l|l|}
\hline & $\begin{array}{l}\text { Post-Confucian systems } \\
\text { (East Asia \& Singapore) }\end{array}$ & US system & $\begin{array}{l}\text { Westminster systems } \\
\text { (UK, Australia, New Zealand) }\end{array}$ \\
\hline $\begin{array}{l}\text { Dynamics of } \\
\text { research }\end{array}$ & $\begin{array}{l}\text { Part household funding of } \\
\text { tuition, ideology of WCU, } \\
\text { university hierarchy- } \\
\text { together enable rapid state } \\
\text { investment in research at } \\
\text { Scale. Applied is dominant. } \\
\text { State intervention }\end{array}$ & $\begin{array}{l}\text { Research heavily } \\
\text { funded by federal } \\
\text { government } \\
\text { unburdened by } \\
\text { tuition. Industry and } \\
\text { philanthropic money. } \\
\text { Basic science plus } \\
\text { commercial IP }\end{array}$ & $\begin{array}{l}\text { Research funded (more in UK) } \\
\text { by government, also finances } \\
\text { tuition. Less philanthropy than } \\
\text { US. Basic science, applied } \\
\text { growth, dreams of IP }\end{array}$ \\
\hline $\begin{array}{l}\text { Hierarchy } \\
\text { and social } \\
\text { selection }\end{array}$ & $\begin{array}{l}\text { Steep university hierarchy. } \\
\text { 'One-chance' universal } \\
\text { competition with selection } \\
\text { into prestigious institutions. } \\
\text { WCUs are fast track for life }\end{array}$ & $\begin{array}{l}\text { Steep institutional } \\
\text { hierarchy mediated } \\
\text { by SAAT scores. } \\
\text { Some part second } \\
\text { chances, mainly } \\
\text { public sector. Top } \\
\text { WCUs are fast track } \\
\text { for life }\end{array}$ & $\begin{array}{l}\text { Competition for place in } \\
\text { university hierarchy mediated } \\
\text { by school results with some } \\
\text { part second chances. WCUs } \\
\text { provide strong start }\end{array}$ \\
\hline $\begin{array}{l}\text { Fostering of } \\
\text { world-class } \\
\text { universities }\end{array}$ & $\begin{array}{l}\text { Part of tradition, universal } \\
\text { target of family aspirations. } \\
\text { Support for building of } \\
\text { WCUs by funding and } \\
\text { regulation. Emerging global } \\
\text { agenda }\end{array}$ & $\begin{array}{l}\text { Entrenched hierarchy } \\
\text { of Ivy League } \\
\text { and flagship state } \\
\text { universities, via } \\
\text { research grants, } \\
\text { tuition hikes, } \\
\text { philanthropy. Source } \\
\text { of global pride }\end{array}$ & $\begin{array}{l}\text { Ambivalence in national } \\
\text { temperament and government } \\
\text { policy on status of top } \\
\text { institutions. Private and public } \\
\text { funding hit ceilings }\end{array}$ \\
\hline
\end{tabular}

Source: Author.

University organisation in Australia has much in common with its regional counterparts, especially in science. Yet concepts like state responsibility, civil society, public interest and academic freedom are practised differently in much of East Asia (see also the introduction to this volume). For example, whereas US universities are often understood as part of civil society, or the market, in East Asia it is inconceivable that even private universities could be located outside the state. Japan and South Korea have prestigious private universities, including Yonsei, Korea University and Ewha in South Korea, and Waseda and Keio in Japan. Government regulation, however, plays a larger role in the running of these universities than it does in the case of their counterparts in the United States.

What about academic freedom? Resources affect the capacity to exercise freedoms. The economic instrumentalism common to all post-Confucian systems (and many others) weakens the humanities and humanistic social sciences vis-à-vis the applied sciences and technologies. Political repression also affects freedoms. There is no blanket repression of criticism in post-Confucian universities. Dissent is expressed in distinctive ways. Issues openly debated or subject to ritualistic angst in Australia are often discussed inside the party/ state in China; the universities are part of the state, broadly defined. In leading 
universities, the atmosphere is often liberal with more potent academic presence in policy issues than in Australia. Yet open public criticism is rare, because it must confront state legitimacy. In the Chinese tradition, scholars have a responsibility to serve the state. This means that they must criticise the state when it departs from the path of legitimate conduct. They openly challenge the regime not whenever they disagree but when they believe it has lost the mandate to govern. This generates acts of individual courage that can trigger state repression - a recurring pattern in China that affects some social scientists and humanists today. Their criticism is not in the form of 'Western-style' assertions of freedom against the state. It is consistent with Sinic tradition and post-Confucian order. Debate is more open in South Korea, Taiwan and Japan, but it takes courage to defy the state and conservative peers.

The meanings of 'university autonomy' and 'academic freedom' vary. There is a universal component - in all systems, faculty like making decisions on their own behalf - and there are culturally variant elements. In the post-Confucian world, the autonomous personality of the university is mostly expressed on behalf of government, not against it. Likewise, academic freedom is understood in terms of authority and responsibility:

Once one can excel in terms of productivity and meet the State's criteria for producing valuable and useful knowledge, one may enjoy a high level of intellectual authority. This type of intellectual authority is not identical with academic freedom in the Western context, but in some ways it provides even more flexibility and greater power than does academic freedom. There is certainly some overlap between these two concepts, yet clearly a different emphasis. Westerners focus on restrictions to freedom of choice, whereas Chinese scholars looking at the same situation focus on the responsibility of the person in authority to use their power wisely in the collective interest. (Zha 2011: 464)

Freedom is understood more in terms of positive freedom than negative freedom. Does this cultural difference limit research outputs? It is unlikely to reduce the quantity of science. In relation to quality and creativity, time will tell. What about the imagination in the humanities? Here, modern economism may be a larger problem than state tradition. It is likely that the post-Confucian systems will develop new humanistic scholarship that embodies both indigenous and global influences, as is already the case in the arts. This may be key to the evolution of the post-Confucian model. To join this conversation, Australian universities will need a larger capacity in East Asian languages and traditions. East Asians know English, but English-speaking universities know little of East Asia. 


\section{Moving forward}

Is there scope for non-Confucian higher education to adapt features of the postConfucian model? Neither the Sinic state nor the Confucian family is readily transplanted. Nevertheless, Australian policymakers could adopt a longer-term view and focus public investment on reforms that would increase participation and the quality and quantity of research. The government did this in 1957-75 in Australia when modern mass higher education and university research were built. The political conditions for such a transformation do not yet exist. The obstacles include small-tax politics and resistance to building selected global research universities. Even The Australian National University's special research funding is being folded back into the one-size-fits-all approach that is the negative legacy of the Dawkins reforms (Marginson and Marshman 2013). Australian institutions are enterprising but of one middling type. In future, regional expectations will be set more by East Asian systems than by Australia. Local universities will need to add more value at the top end to be regionally effective.

Table 11.5 Joint publication of Australian-authored science, by selected partner countries: 1.00 = expected rate of collaboration based on overall collaboration patterns of the two countries

\begin{tabular}{|l|r|r|}
\hline & $\mathbf{1 9 9 5}$ & $\mathbf{2 0 1 0}$ \\
\hline South Africa & 1.86 & 1.50 \\
\hline United Kingdom & 1.05 & 1.16 \\
\hline Ireland & 0.42 & 0.97 \\
\hline Canada & 0.76 & 0.89 \\
\hline United States & 0.80 & 0.75 \\
\hline Germany & 0.52 & 0.60 \\
\hline France & 0.37 & 0.58 \\
\hline Brazil & 0.27 & 0.56 \\
\hline
\end{tabular}

\begin{tabular}{|l|r|r|}
\hline & $\mathbf{1 9 9 5}$ & $\mathbf{2 0 1 0}$ \\
\hline New Zealand & 4.49 & 3.92 \\
\hline Singapore & 2.01 & 1.66 \\
\hline China & 1.11 & 1.06 \\
\hline India & 0.61 & 0.77 \\
\hline Taiwan & 0.30 & 0.68 \\
\hline Japan & 0.60 & 0.64 \\
\hline South Korea & 0.33 & 0.47 \\
\hline Russia & 0.31 & 0.42 \\
\hline
\end{tabular}

Source: Adapted from NSF (2013).

It is noticeable that even the White Paper agenda in higher education would have rested on universities lacking post-Confucian state support. Here, as elsewhere, everything will depend on the willingness of Australian universities to tool themselves within the current resource envelope and apply that new capacity to collaborations in Asia. As Table 11.5 shows, Australian research collaboration with Singapore is strong, it is above the expected level in China but relatively low with South Korea, Japan and Taiwan. Australian science had a slightly greater international edge in collaboration with China in 1995 (1.11) than 2010 (1.06). The latter figure was similar to the US-Chinese rate (1.05). 
The Chief Scientist's Office has suggested one structural initiative that could advance the scope for research collaboration: the formation of an 'Asian-area research zone':

To gain maximum benefit from our [science, technology, engineering and mathematics (STEM)] investments in knowledge generation, we must link to the work of the international community ... Many of the challenges that confront Australia are similar to those of our regional neighbours. There is now an opportunity to share talents, skills, expertise and infrastructure that arises rarely. Accordingly, it is proposed that Australia seek to enter into a partnership with neighbours to establish an Asian-Area Research Zone. (Chubb 2013: 18)

An Asian-area research zone could be developed as a partnership-based research program similar to the European Research Area. Each participating country could provide a share of the total funding based on size and capacity to pay. Grants would be peer-reviewed and awarded only to cross-country partners and teams. As noted above, there are currently some barriers, including linguistic ones, to increasing Australian humanities and social science academics' formal inclusion in regional arrangements. In scientific research, however, the benefits of cooperation are apparent and there is likely to be more support for the inclusion of Australian researchers. More than education exports, research provides Australians with the opportunity to transcend neo-colonial relations through partnerships of genuine equality. This must be central to Australian strategy in the region.

\section{References}

ADB [Asian Development Bank]. 2010. Key indicators for Asia and the Pacific 2009. Manila: ADB.

ARWU [Academic Ranking of World Universities]. 2013. Shanghai Jiao Tong University Graduate School of Education. Shanghai: Shanghai Ranking Consultancy. URL: www.shanghairanking.com/index.html. Consulted 10 November 2014.

Cherlino, Daniel. 2007. A social theory of the nation-state. Oxon: Routledge.

Chubb, Ian. 2013. Science, technology, engineering and mathematics in the national interest. Canberra: Chief Scientist's Office. URL: www.chiefscientist. gov.au/wp-content/uploads/STEMstrategy290713FINALweb.pdf. Consulted 10 November 2014. 
Commonwealth of Australia. 2012. Australia in the Asian Century. White Paper. Canberra: Commonwealth of Australia. URL: www.asiaeducation.edu.au/ verve/_resources/australia-in-the-asian-century-white-paper.pdf. Consulted 10 November 2014.

Croucher, Gwilym, Marginson, Simon, Norton, Andrew and Wells, Julie. eds. 2013. The Dawkins revolution 25 years on. Melbourne: Melbourne University Publishing.

Cruz, Isagani R. 2008. Challenging ISI Thomson Scientific's journal citation reports: Deconstructing 'objective,', 'impact' and 'global'. Libraries and the Academy 8(1): 7-13.

de Vasconcelos, Alvaro. ed. 2012. Global trends 2030: Citizens in an interconnected and polycentric world. Paris: European Union Institute for Security Studies. URL: $\quad$ www.iss.europa.eu/publications/detail/article/espas-report-globaltrends-2030-citizens-in-an-interconnected-and-polycentric-world/. Consulted 10 November 2014.

Henshall, Ken. 2007. History. In Chris Rowthorn (coordinating author), Japan. Melbourne: Lonely Planet.

Leiden University. 2013. The Leiden ranking 2013. Leiden: Centre for Science and Technology Studies. URL: www.leidenranking.com/default.aspx. Consulted 10 November 2014.

Levin, Henry. 2011. Teachers college, Columbia University. Conversation with the author. 26 September, Melbourne.

Marginson, Simon. 2011a. Higher education in East Asia and Singapore: Rise of the Confucian model. Higher Education 61(5): 587-611.

Marginson, Simon. 201 lb. Imagining the global. In Roger King, Simon Marginson and Rajani Naidoo, eds. Handbook of higher education and globalization. Cheltenham: Edward Elgar.

Marginson, Simon. 2012. Global university rankings: The strategic issues. Keynote address to conference at National University of Mexico. 17-18 May, Mexico City. URL: www.cshe.unimelb.edu.au/people/marginson_ docs/Latin_American_conference_rankings_17-18May2012.pdf. Consulted 10 November 2014.

Marginson, Simon and Marshman, Ian 2013. System and structure. In Gwilym Croucher, Simon Marginson, Andrew Norton and Julie Wells, eds. The Dawkins revolution 25 years on. Melbourne: Melbourne University Publishing. 
NSF [National Science Foundation]. 2013. Science and technology indicators 2012. Arlington, VA: National Science Board. URL: www.nsf.gov/statistics/ seind 12/. Consulted 10 November 2014.

OECD [Organisation for Economic Cooperation and Development]. 2013a. Education at a glance 2011: OECD indicators. Paris: OECD.

OECD. 2013b. PISA 2012 results in focus. What 15 year olds know and what they can do with what they know. Paris: OECD.

OECD. 2013c. Science and technology indicators. Paris: OECD.

Postiglione, Gerard. 2011. The rise of research universities: The Hong Kong University of Science and Technology. In Phillip Altbach and Jamil Salmi, eds. The road to academic excellence: The making of world-class research universities. Washington, DC: The World Bank.

Pyne, Christopher. 2014. Commonwealth Minister for Education. House of Representatives Hansard 26 August: 32.

Shin, Jung Cheol. 2009. Building world-class research university: The Brain Korea 21 project. Higher Education 58(5): 669-88.

Smolentseva, Anna 2003. Challenges to the Russian academic profession. Higher Education 45: 391-424.

$\mathrm{Tu}$, Wei-Ming. 1996. Introduction. In Wei-Ming Tu, ed. Confucian traditions in East Asian modernity: Moral education and economic culture in Japan and the four mini-dragons. Cambridge, MA: Harvard University Press.

UNESCO [United Nations Educational, Scientific and Cultural Organisation]. 2013. Tertiary indicators. Paris: UNESCO Institute for Statistics. URL: stats. uis.unesco.org/unesco/TableViewer/tableView.aspx?ReportId=167\&IF_ Language $=$ eng. Consulted 10 November 2014.

Valimaa, Jussi. 2011. The corporatisation of national universities in Finland. In Brian Pusser, Ken Kempner, Simon Marginson and Imanol Ordorika, eds. Universities and the public sphere: Knowledge creation and state building in the era of globalisation. New York: Routledge.

Wang, Qing Hui, Wang, Q. and Liu, Nian Cai. 2011. Building world-class universities in China: Shanghai Jiao Tong University. In Phillip Altbach and Jamil Salmi, eds. The road to academic excellence: The making of world-class research universities. Washington, DC: The World Bank. 
Zha, Qiang. 2011. Is there an emerging Chinese model of the university? In Ruth Hayhoe, Jun Li, Jing Lin and Qiang Zha, eds. 2011. Portraits of 21st century Chinese universities. Hong Kong: Springer/Comparative Education Research Centre, University of Hong Kong. 
This text is taken from The Social Sciences in the Asian Century, edited by Carol Johnson, Vera Mackie and Tessa Morris-Suzuki, published 2015 by ANU Press, The Australian National University, Canberra, Australia. 